\title{
ПЕААГОГІЧНІ НАУКИ
}

DOI: https://doi.org/10.32839/2304-5809/2019-9-73-75

УДК 159.923:057.89

Баклашова Т.М., Шейкаш А.O.

Донбаський державний педагогічний університет

\section{ЗМІСТ КУРСУ ІСТОРІї УКРАЇНИ У ВИЩІЙ ШКОЛІ В УМОВАХ СУЧАСНОЇ МЕТОДОЛОГІЇ ІСТОРІОПИСАННЯ}

\begin{abstract}
Анотація. Статтю присвячено вивченню необхідності змістовного оновлення курсу історії України у вищій школі у відповідності до сучасних методологічних вимог. В якості основоположного методологічного підходу визначено принцип антропологізації історичного знання. З'ясовано основні напрями оновлення змісту викладання історії у вищій школі у відповідності до названого підходу. Визначено основні можливості застосування вказаного методологічного підходу до розробки змісту курсу історії України та встановлено, які саме перспективи він відкриває. Досліджено можливості розвитку навчальної мотивації, формування загальних та спеціальних компетентностей, закріплення світоглядних установок студентів за допомогою оновлення змісту курсу історії України у відповідності до вимог принципу антропологізації. Визначено перспективи подальших досліджень у вказаному напрямі.
\end{abstract}

Ключові слова: вища освіта, зміст навчання, методологія, антропологізація історичного знання, курс історії України.

Bakhlashova Tamara, Sheykash Alina Donbass State Pedagogical University

\section{CONTENTS OF THE UKRAINIAN HISTORY COURSE IN HIGHER SCHOOL IN THE MODERN METHODOLOGY OF HISTORICAL DESCRIPTION}

Summary. The article examines the requirements for updating the content of the Ukrainian History course in accordance with the main tasks of modern higher education. It is noted that the modern educational process must ensure the full development of the professional and the individual, so it is necessary to significantly update the content of historical education on the basis of the latest methodological approaches. The basic requirement for updating the content of historical education is defined by the principle of anthropologization, which understands the historical process as the vital activity of individuals. The study is based on the existing approaches in modern science, formulated in the works of V. Lugovoi, O. Pometun, O. Udoda, T. Charkina, N. Yakovenko and others. The main purpose of the article was to explore the possibility of applying the principle of anthropologizing of historical knowledge as one of the most promising methodological approaches in updating the content of the course of history of Ukraine in higher education. On the basis of the conducted research it is determined that the application of the principle of anthropologization of historical education gives the opportunity to form students' outlook and values which are necessary for the modern world. An important mean of updating the content of the Ukrainian History course, taking into account the requirements of the methodological principle of anthropologization, is the special selection of historical sources for study. It is established that should be selected the historical sources, which would represent various examples of social interaction of people in everyday practices, and testify to the individual experience of the individual. Throughout their future professional and social activities, students who have studied the history of their country through anthropological methodology can use communication and information competences not only for historical research but also for personal development to a much greater extent. Prospects for further research in this direction can be determined as the task for creating training programs, teaching aids and textbooks within the proposed methodological approach.

Keywords: higher education, content of teaching, methodology, anthropologization of historical knowledge, Ukrainian History course.

$\Pi$ остановка проблеми. Сучасна історіографрія в умовах глобалізації та постмодерну виступає не стільки сферою наукового знання, скільки частиною суспільної практики. Історіоградрія є важливим засобом творення суспільством власної історичної пам'яті як частини спільної системи цінностей. На відміну від попередніх часів, сьогодні кожний член суспільства виступає активним суб'єктом творення власної спільноти, в тому числі і в частині уявлень про спільне минуле. При цьому головною умовою для успішної життедіяльності особистості сьогодні визнається можливість їі саморозвитку та повноцінної реалізації власних можливостей. Це, в свою чергу, вимагає від особистості активної участі в суспільному житті, усвідомленої громадянської позиції, відповідальності за існування держави. Відповідно одним із головних завдань сучасної вищої освіти $є$ фороування й розвиток у молодої людини необхідних для самореалізації в суспільстві знань, навичок та рис особистості. У відповідності до цих завдань освітній процес сучасної вищої школи повинний бути організованим не лише як засвоєння суми знань, а насамперед як процес формування системи компетентностей, необхідних для повноцінного становлення майбутнього профресіонала та успішної життевої самореалізації індивідуума. Цим же вимогам має 
відповідати і курс історії України у вищій школі. Забезпечення реалізацї цих вимог, в свою чергу, вимагає суттевого змістовного оновлення викладання історії у відповідності до сучасної ситуащії зміни парадигми історіописання й пошуку новітніх методологічних підходів в сорері історичного знання. Сьогодні істориками чітко усвідомлюеться необхідність зміни методологічних підходів до дослідження історичного процесу і пропонується декілька перспективних напрямів цих змін. Проте основоположною вимогою до пошуку нової методології історичної науки є принцип антропологізаціі, тобто розуміння історичного процесу як перш за все життедіяльності конкретної особистості. Отже, змістовне оновлення курсу історії України у вищій школі в сучасних умовах має відбуватись насамперед у відповідності з вимогами џього методологічного підходу.

Аналіз останніх досліджень і публікацій. Методологічні та методичні аспекти пошуку нових підходів до оновлення змісту вищої освіти $\epsilon$ на сьогодні одним зі найбільш актуальних завдань, відповідно часто виступають предметом вивчення вітчизняних науковців. Зокрема, теоретичні й методичні аспекти реалізації нових підходів в освіті були предметом вивчення таких науковців, як В. Луговий [3], Т. Медведовська [4], М. Могильнер [5], О. Пометун [6]. Так само докладно висвітлювались проблеми змістовного наповнення історичного знання, зокрема в працях В. Гончаревського [1], О. Коляструк [2], О. Удода [7], Т. Чаркіної [8], Н. Яковенко [9] та ін.

Виділення раніше не вирішених частин загальної проблеми. Незважаючи на те, що окремі частини сформульованої проблеми на сьогодні досить докладно висвітлені, комплексно питання застосування методологічних підходів до оновлення змісту викладання історії у відповідності до сучасних суспільних вимог на сьогодні не розглядалось.

Отже, метою даної статті є дослідити можливості застосування принципу антропологізації історичного знання як одного 3 найбільш перспективних методологічних підходів до оновлення змісту курсу історії України у вищій школі.

Виклад основного матеріалу дослідження. Предмети гуманітарного циклу і курс історіі України зокрема в системі вищої освіти виконують не лише освітні, але й виховні завдання. Конкретно курс історії України у вищій школі має забезпечити формування комплексу громадянських та суспільних компетентностей, насамперед глибинне усвідомлення студентами власної історичної та громадянської суб'єктності. Це завдання організаційно вирішуеться завдяки забезпеченню в змісті навчального матеріалу пильної уваги до особистості, розуміння конкретної людини в якості суб'єкта історичного процесу. В сучасному суспільстві студенти завдяки досягненням інформаційних технологій та в умовах глобалізованого світу мають незрівнянно кращі можливості для залученості до загальносвітової культури. Водночас глобальні економічні, політичні й культурні процеси несуть загрозу дегуманізації людини в повсякденному житті. Для збереження в цих умовах розуміння самоцінності особистості, в тому числі як суб'екта історії, icторичне знання має оперувати вже усталеними науковими категоріями, такими як народ, нація, держава, суспільство тощо, проте розуміти їх як добровільні об'єднання конкретних людей, засновані на спільній системі цінностей та здатних до взаємозбагачення на основі діалогу [9]. Розуміння окремої національної історії сьогодні можливе лише в загальнолюдському контексті, як складової частини величезної системи, яка включає не лише людські суспільства та матеріальні і нематеріальні продукти їхньої діяльності, але й природне оточення.

Наближення історичного знання до конкретної особистості забезпечуе в курсі історії України у вищій школі розвиток цілої групи важливих компетентностей, необхідних майбутньому профресіоналу, а саме здатності до організації успішної комунікації як діалогу. В змісті історичної освіти вирішенню цього завдання має сприяти включення до змісту навчання належної кількості відомостей з так званої історії повсякденності [2]. Змістом цього методологічного підходу сьогодні розуміється дослідження історичного процесу як системи повсякденного життя людини з урахуван-

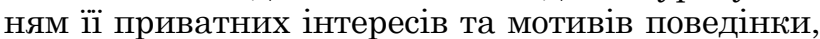
індивідуально важливих вчинків та їх наслідків. В рамках такого підходу історичною суб'єктністю наділяються всі члени суспільства та громади. Такий підхід дає можливість поглибити у студентів відчуття власної суб'єктності та розвинути повагу до різноманіття людського суспільства як передумову для успішної комунікації.

Важливим завданням курсу історії України у вищій школі є також формування у студентів переконання в самоцінності кожної людської особистості як стійкої світоглядної установки. Вирішенню цього завдання має сприяти дотримання в процесі розробки змісту історичної освіти принципу антропологізації, який вимагає розглядати історичний процес не 3 точки зору державних, національних або партійних інтересів, а 3 точки зору суспільства і громадянина. Розуміння суспільного блага та історичного прогресу в рамках цієї методології також усвідомлюеться через повсякдення, чим підкреслюеться найвища цінність людського життя [1].

Сучасному фрахівцю 3 вищою освітою для успішного становлення й розвитку необхідно опанувати цілим комплексом комунікативних компетентностей, що включають які передбачають особистісну здатність та операційні вміння до ефрективної роботи в групі, спроможність в процесі професійної діяльності успішно реалізувати систему взаємовідносин із суспільством, вміння сполучати індивідуальну ініціативу й відповідальність із високим рівнем соціальної емпатії [3]. В системі вищої освіти дрормування цих компетентностей забезпечується в тому числі і через розробку змісту освіти. В структурі історичної освіти застосування методологічного принципу антропологізації до оновлення змісту навчального матеріалу надає можливості до розвитку у студентів насамперед світоглядної установки на успішну самореалізацію через активну діяльність в інтересах суспільства [7]. Таке оновлення змісту викладання національної історії передбачає водночас розширення пропонованої студентам інформації про роль видатних особистостей в історичному процесі та забезпечення 
достатнього рівня відомостей щодо участі широких мас та різноманітних суспільних груп в подіях та умов повсякденного життя людей певної епохи. Завдяки цьому забезпечуеться усвідомлення історичної суб'єктності та відповідальності кожної без винятку людини та громади. Таке усвідомлення, в свою чергу, стає могутнім мотиваційним фрактором до опанування комунікативними компетентностями, а конкретний фрактографічний матеріал надає необхідної інформації для фрормування суспільного досвіду.

В умовах сучасного інформатизованого суспільства важливим завданням вищої освіти $є$ фрормування й розвиток у студентів вміння знаходити та опрацьовувати необхідну інформацію, а також здатності самостійно здійснювати продуктивну творчу діяльність. Змістовне оновлення курсу історії України серед інших засобів також дає можливість розширити й поглибити ці вміння. Застосування принципу антропологізації до розробки змістовного наповнення кожної із складових курсу історичного знання передбачає зокрема і висвітлення всього комплексу мотивів діяльності видатних та пересічних учасників історичного процесу, суспільних груп різного кількісного складу, а також всіеї системи наслідків прийнятих рішень для індивідуума та групи. Внаслідок цього у студентів формуеться чітке розуміння відповідальності індивідуума та групи за наслідки прийнятого рішення, в тому числі і за наслідки реалізації власних творчих здібностей та нестандартних підходів до вирішення проблем. Розвиваючи водночас мотиващію до прояву власних креативних здібностей, матеріал курсу нащіональної історії дає достатню кількість конкретних і яскравих прикладів залежності перебігу та наслідків історичного процесу від творчої активності особистості та колективу. Поглиблення уваги до особистісних мотивів творчої активності дає молодій людині необхідну фактографрічну інформацію для формування власних ціннісних установок щодо можливих напрямів прояву власної креативності та забезпечує необхідні запобіжники від занадто радикальних історичних рішень.

Необхідною частиною історичної освіти є опанування студентами навичок роботи 3 історичними джерелами [6]. Ця складова навчального процесу є традиційною, однак зміст навчальних тем, 3 яких пропонується опрацювання історичних джерел, характер та тематики цих джерел також потребують значного змістовного оновлення із застосуванням сучасних методологічних вимог. Конкретним засобом оновлення змісту курсу із врахуванням вимог методологічного принципу антропологізації в контексті вивчення історичних джерел виступає відбір джерел для вивчення, які б репрезентували різноманітні приклади соціальної взаємодії людей у повсякденних практиках, свідчили про індивідуальний досвід особистості [8]. Відповідно слід якомога ширше i різноманітніше представляти історичні джерела особистісного характеру, матеріали усної історії, активніше надавати візуальні джерела (фотографріi, кінофрільми тощо). Через такий матеріал створюється у студентів відчуття особистісної залученості до історичного процесу, індивідуальної соціальної емпатії. Крім того, вивчення різноманітних історичних джерел особистісного характеру розвиватиме у студентів усвідомлення важливості навичок критичного аналізу отриманої інфрормації, необхідності врахування рівня об'єктивності отриманої індормації. Крім того, опрацювання у відповідності до вимог принципу антропологізації історичного знання значної кількості історичних джерел особистісного характеру поступово закріплюе у студентів розуміння того, що створені в процесі індивідуального спілкування тексти часто 3 плином часу перетворюються на історичне джерело, відповідно до власної комунікації слід ставитись більш уважно.

В процесі роботи над курсом історії України, зміст якого розроблено у відповідності до сучасних методологічних вимог, студенти мають можливість глибоко зрозуміти представників різноманітних етнічних груп, національних меншин, релігійних конфесій, соціальних спільнот, з яких складаеться українська нація. Включення до змісту викладання відомостей 3 мікроісторії дозволяе сформувати у студентів таку необхідну складову компетентності сучасного громадянина та фрахівця, як здатність до міжкультурної комунікації [1]. Розкриття через мікроісторію культурного смислу побутових практик дає можливість зрозуміти основоположні цінності та ідеали, світоглядні принципи окремих людських спільнот і тим самим глибше усвідомити відмінності між різними групами в рамках одного суспільства. Такий підхід до формування змісту історичної освіти дозволяе сформувати і закріпити у молодої людини ціннісну установку на співгромадянина як індивідуальність, носія важливих культурних смислів, рівноцінного співрозмовника [8].

Вищеназвані можливості застосування принципу антропологізащії до оновлення змісту курсу історії України у вищій школі є незаперечно важливими, проте вони не можуть бути належним чином реалізовані в продесійній діяльності та особистісному становленні без вирішення головного завдання вищої освіти, а саме формування світоглядної установки на безперервний саморозвиток і самоосвіту протягом всього життя [4]. В рамках курсу історії України вирішення цього завдання здійснюеться через формування основ світогляду та ціннісних орієнтацій. Застосування принципу антропологізації змісту історичної освіти для забезпечення світоглядного розвитку молоді передбачає розгляд національної історії 3 точки зору особистості, але на рівні цивілізаційних процесів. Сполучаючи гранично широке узагальнення історичних відомостей із розглядом індивідуального життевого сценарію особистості в умовах певної цивілізації, викладач і студент мають можливість представити та проаналізувати історичний процес як не випадковий, а об'єктивно обумовлений та цілеспрямований, в якому саме особистість виступає творцем смислів [1]. Формування такої світоглядної позиції забезпечує значно вищий рівень відповідальності молоді за життя суспільства, убезпечити студентів від проявів ксенофобії, розвиває усвідомленість цінностей европейської цивілізації. На основі такої світоглядної установки можливо здійснювати активний процес саморозвитку протягом всього життя, збагачуючи свій культурний потенціал цінностями національної та загальнолюдської культури. 
Висновки і перспективи подальших досліджень. Із проведеного дослідження можна зробити висновок про необхідність змістовного оновлення курсу історії України у вищій школі у відповідності до сучасних вимог суспільства. Таке оновлення необхідно проводити у відповідності до розроблених науковцями методологічних підходів, більшість яких можуть бути окреслені в рамках принципу антропологізації історіографpiï. Наближення історичного знання до потреб і вимог конкретної особистості, відмова від надання історичної суб’ектності виключно інституціоналізованим людським спільнотам дає можливість сформувати у студентів необхідні для сучасності світоглядні установки та цінності. Протягом всієї майбутньої профресійної та суспільної діяльності студенти, які вивчали історію своєї держави в рамках методології антропологізації, можуть значно краще застосувати комунікаційні та інформаційні компетентності не лише для історичних досліджень, але і для особистісного саморозвитку. Перспективами подальших досліджень у вказаному напрямку можна визначити завдання створення навчальних програм, методичних посібників та підручників в рамках запропонованого методологічного підходу.

\section{Список літератури:}

1. Гончаревський В.Г. Цивілізаційний підхід до історії: сучасний український досвід. Київ, 2011. 220 с.

2. Коляструк О.А. Методологія історії повсякдення. Вісник Харківського національного університету іл. В. Каразіна. Серія : Iсторія. 2011. Вип. 44. С. 8-21.

3. Луговий B.I. Європейська концепщія компетентнісного підходу у вищій школі та проблеми ії реалізації в Україні. Педагогіка і психологія. 2009. № 2. С. 13-26.

4. Медведовська Т. Компетентнісний підхід у організації навчального процесу в системі вищої освіти. Гуманізація навчально-виховного процесу. 2011. Вип. 7. С. 40-45.

5. Могильнер М. Як писати підручник з історії: досвід і нові виклики. Сучасні дискусї̈ про Другу світову війну. Київ, 2012. С. 190-196.

6. Пометун O.I. Реалізація компетентнісного підходу в навчанні історії. Київ, 2012. URL: http//slideshare.net/ ippo-kubg/ss-52240198 (дата звернення: 07.08.2019).

7. Удод О.А. Історія повсякденності як провідний напрям української історіографії. Краєзнавство. 2010 . № 3. C. 6-9.

8. Чаркіна Т.І. Антропологізація історичного знання в період постмодерну. Гілея. 2014. Вип. 89. С. $210-214$

9. Яковенко Н. Концепція нового підручника з української історії. Історія Украӥни. 2010. № 29. С. 13-19.

\section{References:}

1. Honcharevskyi, V.H. (2011). Tsyvilizatsiinyi pidkhid do istorii: suchasnyi ukrainskyi dosvid [Civilizational approach to history: the vodern ukrainian experience]. Kyiv : Logos. (in Ukrainian)

2. Koliastruk, O.A. (2011). Metodolohiia istorii povsiakdennia [Methodology of the history of everyday life]. Visnyk Kharkivskoho natsionalnoho universytetu im. V. Karazina. Seriia : Istoriia, vol. 44, pp. 8-21.

3. Luhovyi, V.I. (2009). Yevropeiska kontseptsiia kompetentnisnoho pidkhodu u vyshchii shkoli ta problemy yii realizatsii v Ukraini [European concept of competent approach in the high education and the problems it's realization in Ukrain]. Pedahohika i psykholohiia, vol. 2, pp. 13-26.

4. Medvedovska, T. (2011). Kompetentnisnyi pidkhid u orhanizatsii navchalnoho protsesu v systemi vyshchoi osvity [The competent approach in the organisation of the educations processes in system of high education]. Humanizatsiia navchalno-vykhovnoho protsesu, vol. 7, pp. 40-45.

5. Mohylner, M. (2012). Yak pysaty pidruchnyk z istorii: dosvid i novi vyklyky [How to write a history textbook]. Suchasni dyskusii pro Druhu svitovu viinu [Vodern oppositiones about of second World War]. Kyiv : Osvita.

6. Pometun, O.I. (2012). Realizatsiia kompetentnisnoho pidkhodu v navchanni istorii [Realisation of the competent approach in the history education]. Avialable at: http//slideshare.net/ippo-kubg/ss-52240198 (accessed: 07.08.2019).

7. Udod, O.A. (2010). Istoriia povsiakdennosti yak providnyi napriam ukrainskoi istoriohrafii [The history of everyday life as a leading direction of ukrainian historiographi]. Kraieznavstvo, vol. 3, pp. 6-9.

8. Charkina, T.I. (2014). Antropolohizatsiia istorychnoho znannia v period postmodernu [Antropologization of the historical knowlege in the period of postmodern]. Hileia, vol. 89, pp. 210-214.

9. Yakovenko, N. (2010). Kontseptsiia novoho pidruchnyka z ukrainskoi istorii [Concept of the new ukrainian textbook]. Istoriia Ukrainy, vol. 29, pp. 13-19. 